\title{
Insulin and Lipoperoxide
}

\author{
Kazuo KATSUMATA and Kouzo YAMADA \\ Third Department of Internal Medicine, Faculty of Medicine, Nagoya University, \\ Nagoya, Japan (Director : Professor K. Yamada)

\section{Ikuo NISHIGAKI, Naoki YAMANAKA and Takayuki OZAWA} \\ Department of Biochemistry, Faculty of Medicine, Nagoya University \\ (Director : Professor K. Yagi)
}

The relationship between insulin and lipoperoxide was studied. The following results were obtained.

1. The levels of T.B.A. on the liver of insulin deficient alloxan diabetic rats were observed with or without V.E. and were compared with the levels of TBA on the liver of control rats. Alloxan diabetic rats had higher TBA levels on the liver than that of control rats. On the contrary insulin treatment decreased TBA on the liver of alloxan diabetic rats to normal.

2. The addition of $100 \mathrm{mU}$ pork insulin per $\mathrm{ml}$ of reaction system in vitro markedly decreased TBA level on the liver of normal rats, but did not influence TBA level on the liver of alloxan diabetic rats.

3. The above-mentioned results show that insulin has some biological or pharmacological effect on the TBA and that the increased level of liver lipid observed in the alloxan diabetic rats together with the decreased level of antioxidant must have a causal relation with the increased TBA level on the liver of alloxan diabetic rats.

(See pp. 778 782) 


\title{
インスリンと過酸化脂質に関する研究
}

\author{
名大山田内科 \\ 勝又一夫, 一田弘三 \\ 名大第一生化 \\ 西 垣 郁 雄, 山 中 直 樹 \\ 小沢 高 将
}

(昭和44年 3 月 17 日受付)

アロキサン糖尿病白鼠肝の TBA 值は対照白鼠肝より明らかに高かつた。インスリン治療のアロキ サン糖尿病白鼠肝では, TBA 值の上昇はなかつた。 In vitro のインスリン添加で, 対照白鼠肝 TBA 值は低下したが，アロキサン糖尿病白鼠肝では低下が明らかでなかつた。

In vitro の VE, albumin の添加で, 対照群肝の TBA の低下は明白に認められたが, アロキサン 糖尿病肝では TBA 值の低下は対照群ほどではなかつた，以上の成績に基づき，インスリンと過酸化 脂質に関して $2 ， 3$ の考察を行なつた。

\section{序言}

人動脈壁の atheroma 病変部位より抽出した脂質に大量の過酸化脂質 (lipoperoxide) の存在が証明せら れ, 最近, 動脈硬化の発生要因と動脈壁の lipoperoxide の増加との関係が一部の学者の間で注目されてい る ${ }^{1)}$. ところで人糖㽷病では血管障害が多発し, 糖尿病の死因の第一位は合併する血管病変である。換言す ればインスリン久之，あるいは利用障害時の病態は血管障害の発生に好適な場を提供している。しかしなが ら，それらの理由は明白ではない。

インスリン久之状態では, 周知の如く脂質代謝の異常が存在する. 脂質の増加が存在した場合に, 何らか の要因によつて自動酸化が起てり, lipoperoxide 值が増加する可能性がある. lipoperoxide の增量と血管 障害の発生との密接な関連については, すでに述べた1). インスリン久乏時に lipoperoxide の増加が存在 すれば血管障害の発生を促進するのみならず，朋酵素活性にも影響を及ぼし，糖㽷病の病態を修飾するで あろう。そこで我々は, アロキサンでインスリン欠之性糖尿病白鼠を作り, その lipoperoxide 值を検討し た. 従来, lipoperoxide の測定方法は, 血糖の上昇に併い, その影響で高值を示すなどの, かなりの問題 を含んでいた，我々は脂質を抽出してから測定する西垣，八木等の方法 ${ }^{2}$ 亿從い，血糖に影響されることな く, lipoperoxıde 值を測定し, 興味ある成績を得た。

\section{実 験 方 法}

雄性 Wistar 系白鼠20匹を oriental 固形食と野菜で飼育し，5例の対照群と15例のアロキサン糖尿病群 に分けた。 15例のアロキサン糖尿病群にはアロキサンを $200 \mathrm{mg} / \mathrm{kg}$ 体重当たり腹注し, 7 日後に空腹時血糖 $200 \mathrm{mg} / \mathrm{d} 1$ 以上を示す白鼠10例をアロキサン糖尿病群とした. その中の 5 例は以後レンテインスリンを 1 単 位ずつ 7 日間筋注するアロキサン治療群とし，5例はインスリンを注射しない未治療群とした．アロキサン 注射後14日目に食餌を抜いて 4 時間後に断頭屠殺し, 肝をとりだし, lipoperoxide 值を測定した。測定方 法は Table 1 に示す. Lipoperoxide 值は肝湿重量 $1 \mathrm{~g}$ 当たりの TBA 值として表わした. また肝の一部 については，総脂質を重クロム酸カリ法 ${ }^{3)}$ で測定した。 Table 1 亿示す如く, in vitro に tocopherol 
Table 1. Method of TBA determination

Liver $1 \mathrm{~g}+400 \mathrm{mM} \mathrm{NaCl}$

$100 \mathrm{mM}$ Tris Buffer $6 \mathrm{ml}$

homogenized with polytoron homogenizer

homogenate $1 \mathrm{ml} \stackrel{\downarrow}{+}$ Pork insulin,

Tocopherol acetate, $\quad+\quad$ 100mM Tris Buffer

$0.05 \mathrm{M} 5 \mu \mathrm{l} \quad 400 \mathrm{mM} \mathrm{NaCl}$

Albumin or none was added up to $5 \mathrm{ml}$

$37^{\circ} \mathrm{C} 90 \mathrm{minutes} \stackrel{\downarrow}{\downarrow}$ uncubation (dark)

$\mathrm{CHCl}_{3} \quad 2$

$\mathrm{CH}_{3} \mathrm{OH} \quad \stackrel{1}{1} 20 \mathrm{ml}$ was added and vigorously shaked

10 minutes later

$0.05 \% \mathrm{H}_{2} \mathrm{SO}_{4} 5 \mathrm{ml}$ was added and mixed

10 minutes later,

centrifuge (3000rpm.) 10minutes

$15 \mathrm{ml}$ of $\mathrm{CHCl}_{3}$-layer was gained and divided to three portions.

Each portion containing $5 \mathrm{ml}$ of $\mathrm{CHCl}_{3}$-layer was dried up using rotary

evaporater

gassed with argon $\downarrow \quad \downarrow$ gassed with argon

the determinat

For the determination of TBA value $5 \mathrm{ml}$ of TBA reagent* was added with argon, and was boiled in the water bath at $100^{\circ} \mathrm{C}$ for 60 minutes.

$$
\stackrel{\downarrow}{\downarrow}
$$

$5 \mathrm{ml} \mathrm{CHCl}_{3}$ was added and vigorously shaked

centrifuged (3,000rpm.) 10minutes

coloured layer was taken

$\mathrm{OD}_{532}-\mathrm{OD}_{600}$ was $\stackrel{\downarrow}{\text { read }}$ with spectrophotometer $\downarrow$

$\left(\mathrm{OD}_{532}-\mathrm{OD}_{600}\right) \times \frac{15 \times 7}{5}=\frac{\mathrm{TBA}}{\mathrm{g}}$

*0.67\% Thiobarbituric acid aqueous solution was mixed with the same amount of acetic acid.

acetate, albumin, pork insulin などを加え，肝 TBA 值に及ぼす影響についても検討し，興味ある成績 を得た。

結果

1）アロキサン糖尿病ならびに対照白鼠肝の総脂質と lipoperoxide 值

5 例のアロキサン糖尿病白鼠肝の TBA 值は5.68土1.92で対照白鼠 5 例の TBA 值 $3.07 \pm 0.38$ よりも明 白に高かつた (Table 2)。乙の高值は肝総脂質の増加とかなりよく符合した.

Tocopherol acetate を in vitro で，肝をとりだしてから直ちに加え，全く同様にして測定したが，その 結果 TBA 值は同様にアロキサン糖尿病白鼠肝が対照よりも高值を示した。 しかし, 刘照群, アロキサン 糖尿病群ともに tocopherol acetate 添加時の TBA 值は tocopherol acetate の添加しない場合に比して, かなり低くなつていた (Table 2)。総脂質は，しかしながら tocopherol acetate の有無によつて，著しい 
Table 2. Changes of TBA levels and total fat in liver of untreated alloxan diabetic and control rats

\begin{tabular}{|c|c|c|c|c|c|c|c|c|}
\hline \multirow{3}{*}{ rat No. } & \multicolumn{4}{|c|}{ Untreated alloxan diabetic } & \multicolumn{4}{|c|}{ Control } \\
\hline & \multicolumn{2}{|c|}{$\mathrm{TBA} / \mathrm{g}$ liver } & \multicolumn{2}{|c|}{ total fat $\mathrm{mg} / \mathrm{g}$} & \multicolumn{2}{|c|}{$\mathrm{TBA} / \mathrm{g}$ liver } & \multicolumn{2}{|c|}{ total fat $\mathrm{mg} / \mathrm{g}$} \\
\hline & $\mathrm{VE}(-)$ & $\mathrm{VE}(+)$ & $\mathrm{VE}(-)$ & $\mathrm{VE}(+)$ & $\mathrm{VE}(-)$ & $\mathrm{VE}(+)$ & $\mathrm{VE}(-)$ & $\mathrm{VE}(+)$ \\
\hline 1 & 6.28 & 3.09 & 94.5 & 99.4 & 3.08 & 0.76 & 54.6 & 53.4 \\
\hline 2 & 3.18 & 1.41 & 78.9 & 81.5 & 2.56 & 0.77 & 57.3 & 57.1 \\
\hline 3 & 4.12 & 2.09 & 97.3 & 104.3 & 2.74 & 0.89 & 51.9 & 51.3 \\
\hline 4 & 8.72 & 4.18 & 112.4 & 113.6 & 3.56 & 0.88 & 47.5 & 49.1 \\
\hline 5 & 6.12 & 4.52 & 109.5 & 101.7 & 3.41 & 0.79 & 69.1 & 68.4 \\
\hline $\begin{array}{l}\text { Mean } \\
\pm \text { S.D. }\end{array}$ & $\begin{array}{l}5.68 \\
\pm 1.92\end{array}$ & $\begin{array}{l}3.06 \\
\pm 1.22\end{array}$ & $\begin{array}{l}98.5 \\
\pm 13.7\end{array}$ & $\begin{array}{l}100.1 \\
\pm 10.5\end{array}$ & $\begin{array}{l}3.07 \\
\pm 0.38\end{array}$ & $\begin{array}{l}0.82 \\
\pm 0.06\end{array}$ & $\begin{array}{l}56.1 \\
\pm 10.4\end{array}$ & $\begin{array}{l}55.9 \\
\pm 8.8\end{array}$ \\
\hline
\end{tabular}

$\mathrm{VE}(+)$ or $\mathrm{VE}(-)$ means that tocopherol acetate is added in vitro to the experimental system or not.

変化は見られなかつた。なおアロキサン糖尿病群白 鼠肝での TBA 值は肝 $1 \mathrm{~g}$ 当たりでもまた肝総重 量としてみても，すべて対照に比して高值を示した が，肝脂質当たりの TBA 值として計算すると， アロキサン糖尿病白鼠肝で TBA 值の増加は認め られなかつた。

2) In vivo. In vitro のインスリン効果

アロキサン注射 7 日後に高血糖を示し，糖尿病の 発症をみたアロキサン糖尿病白鼠飞毎日 7 日間 Lente insulin 1 単位の注射をし, 治療してきた 5 例の肝 TBA 值は Table 3 亿示す如くで, Table 2 に示す対照群に比べて増加は見られなかつた。一方,
Table 3. Changes of TBA level and total fat in liver of insulin-treated alloxan diabetic rats

\begin{tabular}{|c|c|c|c|}
\hline \multirow{2}{*}{\multicolumn{2}{|c|}{ rat's No. }} & \multicolumn{2}{|c|}{$\begin{array}{l}\text { insulin treated alloxan diabetic } \\
\text { rats }\end{array}$} \\
\hline & & $\mathrm{TBA} / \mathrm{g}$ liver & total fat $\mathrm{mg} / \mathrm{g}$ \\
\hline & 1 & 3.53 & 59.1 \\
\hline & 2 & 3.01 & 61.4 \\
\hline & 3 & 2.94 & 57.9 \\
\hline & 4 & 3.31 & 59.3 \\
\hline & 5 & 2.77 & 55.1 \\
\hline mean & \pm S.D. & $3.11 \pm 0.29$ & $58.6 \pm 2.0$ \\
\hline
\end{tabular}

Table 4. The effect of insulin addition in vitro to the untreated alloxan diabetic and control rats liver homogenate

\begin{tabular}{|c|c|c|c|c|c|c|c|c|}
\hline \multirow{3}{*}{$\begin{array}{l}\text { rat No. } \\
\text { insulin }\end{array}$} & \multicolumn{4}{|c|}{ untreated alloxan diabetic } & \multicolumn{4}{|c|}{ control rats } \\
\hline & \multicolumn{2}{|c|}{$\mathrm{TBA} / \mathrm{g}$ liver } & \multicolumn{2}{|c|}{ total fat $\mathrm{mg} / \mathrm{g}$} & \multicolumn{2}{|c|}{$\mathrm{TBA} / \mathrm{g}$ liver } & \multicolumn{2}{|c|}{ total fat $\mathrm{mg} / \mathrm{g}$} \\
\hline & $100 \mathrm{~mL}$ & $200 \mathrm{mU}$ & $100 \mathrm{~mL}$ & $200 \mathrm{mU}$ & $100 \mathrm{mU}$ & $200 \mathrm{mU}$ & $100 \mathrm{mU}$ & $200 \mathrm{mU}$ \\
\hline 1 & 6.32 & 6.31 & 93.7 & 97.1 & 3.49 & 3.50 & 57.3 & 57.1 \\
\hline 2 & 3.16 & 3.17 & 76.5 & 80.9 & 2.44 & 2.41 & 59.2 & 59.1 \\
\hline 3 & 4.11 & 4.13 & 99.5 & 113.4 & 2.23 & 2.14 & 50.4 & 51.7 \\
\hline 4 & 8.89 & 8.95 & & & 2.26 & 2.17 & & \\
\hline 5 & 6.16 & 6.11 & & & 2.21 & 2.22 & & \\
\hline $\begin{array}{l}\text { mean } \\
\pm \text { S.D. }\end{array}$ & $\begin{array}{l}5.73 \\
\pm 1.99\end{array}$ & $\begin{array}{l}5.73 \\
\pm 2.01\end{array}$ & $\begin{array}{l}89.9 \\
\pm 6.45\end{array}$ & $\begin{array}{l}97.1 \\
\pm 13.2\end{array}$ & $\begin{array}{l}2.53 \\
\pm 0.49\end{array}$ & $\begin{array}{l}2.49 \\
\pm 0.51\end{array}$ & $\begin{array}{l}55.6 \\
\pm 3.8\end{array}$ & $\begin{array}{l}56.0 \\
\pm 3.1\end{array}$ \\
\hline
\end{tabular}


Table 5. The effect of albumin addition in vitro to the untreated alloxan diabetic and control rats liver homogenate

\begin{tabular}{c|c|c|c|c}
\hline & \multicolumn{2}{|c|}{ untreated alloxan diabetic } & \multicolumn{2}{|c}{ control } \\
\hline rats No. & TBA/g liver & total fat mg/g & TBA/g liver & total fat mg/g \\
\hline \hline 1 & 5.41 & 95.3 & 1.49 & 53.9 \\
2 & 2.77 & 77.6 & 1.21 & 57.4 \\
3 & 3.74 & 99.4 & 1.30 & 51.8 \\
4 & 6.79 & & 1.73 & \\
5 & 5.54 & & 1.56 & \\
\hline mean & $4.85 \pm 0.58$ & $90.8 \pm 9.5$ & $1.46 \pm 0.19$ & $54.2 \pm 2.2$ \\
\hline S.D. & & &
\end{tabular}

$5 \mathrm{mg}$ bovine albumin was added to the experimental system $(1 \mathrm{mg} / \mathrm{ml})$

in vitro で対照ならびにアロキサン未治療糖尿病白鼠肝 homogenate を加え，次いで TBA 值を測定した (Table 4). 肝総脂質はインスリンの添加で著変はなかつたが，TBA 值は対照群で著明に減少した。しかしながら，アロキサン糖尿病群の肝では減少が全くみられなかつた。

$5 \mathrm{mg}$ の bovine albumin を加えてみると, 対照群及びアロキサン糖尿病白鼠肝の TBA は共に減少し たが，アロキサン糖尿病白鼠肝 TBA 值の方が減少は少なかつた (Table 5).

\section{考案}

アロキサン糖疛病白鼠肝で，TBA 值は明白に対照白鼠の肝より高值を示した。しかしながら，肝脂質 $\mathrm{mg}$ 当たりとして計算すると, TBA 值の差がないととから, アロキサン糖尿病では肝脂質の増量がまず存在 し, 次いで過酸化機構の促進, 抗過酸化機構の減弱が加わつて, 肝 TBA 值は増加したものと思われる. 從来すでにVE を始め, 多くの抗過酸化物質が示されているが゙), 抗過酸化, ならびに過酸化物質形成促 進の機構, アロキサン糖尿病白鼠におけるそれらの機構の詳細は明らかではない. ととろで in vitro で $\mathrm{VE}$ を最初より加えると, アロキサン糖尿病群の肝 TBA 值はVE により低下はしたが, 対照群の方が低 下が著明であつたため, 対照群に比べて著しく高值を示した。VEは優れた抗過酸化剤であり, 一般に過酸 化反応を抑制するといわれているので，アロキサン糖尿病肝にみられる TBA 值の増加のすべてが，肝脂 質が実験操作の過程において peroxidation を来たしたためとは考光られず, 生体内で peroxidation の増 加が確かに起つているととを示すものと考光られる。ところで，インスリン治療を行なつたアロキサン糖尿 病白鼠で肝の TBA 值は明白に低下していた。 この事実は，インスリンの治療により肝脂質の増加が見ら れないととと一致する。対照白鼠肝にみられた in vitro でのインスリン添加効果は興味深い. 有効なイン スリン添加量は大量を要し, $100 \mathrm{mU} / \mathrm{ml}$ 以上であつた. かかる in vitroのインスリン効果は対照白鼠肝に のみ認められ，アロキサン糖尿病白鼠肝では殆んど無效であつた。インスリンの抗酸化作用はそのメカニズ ムは不明であるが，注目に值する。 In vitro の有效インスリン濃度, 対照群の白鼠肝にのみインスリンが 有效である事実より，in vitro でのインスリン效果はインスリンそのものが直接生物学的な作用で抗過酸 化作用を示すのか，あるいは薬物的に理解すべきであるのか，不明である．アロキサン糖尿病群の朋で， in vitro のインスリンによる抗過酸化作用がなく, albumin の抗過酸化作用も少いてとは, アロキサン糖㽷病 時に抗過酸化機構の減弱と, 過酸化促進機構の増強を示すものかもしれない. 一般に脂質過酸化物は多くの 酵素活性に対して，障害作用を有するととはよく知られている．門脈血中の高いインスリン濃度より考えて， 生体内でインスリンは抗過酸化剂として働らき，各種酵素を保護している可能性もある．勿論，すでに多く の抗過酸化物質が知られており，インスリンの抗過酸化作用はインスリンのみに特異的なものではない. albumin $1 \mathrm{mg} / \mathrm{ml}$ でも抗過酸化作用があるが，しかしインスリンよりも遙かに大量であるととは興味深い. 
以上，要約するとインスリン久乏時には脂質の増加があり，同時にインスリン欠乏による代謝の乱れより， 抗過酸化機構の減少と過酸化促進機構の増加を来たし，肝 TBA 值の増加が来ると思われる。このような TBA 值の増加は永続すれば，当然血管障害の発生に好適な場を提供するのみならず，朋醉素活性にも何ら かの影響を与え得るかもしれない，なおアロキサン糖尿病白鼠のその他の臟器における TBA 值について は, 血液, 心では対照と差はなく, 各臟器間の差が存在し ${ }^{6)}$, 複雑な因子の関与が推定される.

結

論

1) アロキサン糖尿病白鼠肝では過酸化脂質の増量が存在し，インスリンの治療では増量はみられない. ての増加はVE の添加によつても存在しているので, 生体内で過酸化物が増加したものと思われる。

2) $100 \mathrm{mU} / \mathrm{ml}$ 以上のインスリンの in vitro の添加により対照白鼠肝で過酸化脂質は減少するが，アロ キサン糖尿病白鼠では変動はない.

かかるインスリン作用が生物学的作用か，インスリンの薬物的作用によるのか不明であるが，興味深い現 象である.

3）アロキサン糖尿病白鼠肝の過酸化脂質の増加は肝脂質の増加が基礎となり，糖尿病時の代謝異常のた めに抗過酸化機構の減弱を来たしたととによると思われる。

以上の成績を糖尿病時の血管障害との関連で論じた。

文献

1）福住一雄, 岩田国雄 : 油化学, $12: 93$, (1963). 2) 西垣郁雄, 八木国夫, 小沢高将 : ビタミン, $38: 359$, (1968).

3) BRAGDON, J.H. : J. Biol. Chem., $190: 513$, (1951)

MATTILL, H.A. : Oil and Soap $22: 1$, (1945)

5) TAPPEL, A.L. : Arch. Biochem. Biophy. $54: 266$, (1955)

6) 勝又一夫 : Unpublished data 